\title{
Leiomyoma in the hernia sac of a child: A case report, review of literature, and review of diagnostic challenges
}

\author{
Vanda Farahmand Torous ${ }^{1}$, Daniel DeUgarte ${ }^{2}$, Scott D. Nelson ${ }^{3}$ \\ 1. Department of Pathology, Beth Israel Deaconess Medical Center, United States. 2. Department of Surgery, Pediatric \\ Surgery, University of California, Los Angeles, United States. 3. Department of Pathology and Laboratory Medicine, \\ University of California, Los Angeles, United States.
}

Correspondence: Vanda Farahmand Torous. Address: Department of Pathology, Beth Israel Deaconess Medical Center, United States. E-mail: vtorous@bidmc.harvard.edu

Received: November 15, $2014 \quad$ Accepted: January 22, $2015 \quad$ Online Published: February 11,2015

DOI : 10.5430/crcp.v2n1p97 URL: http://dx.doi.org/10.5430/crcp.v2n1p97

\begin{abstract}
Leiomyomas are benign soft tissue tumors that are common entities depending on their site of occurrence and the age of the patient. They occur more frequently in adults, usually in the fourth to sixth decades, and occur more frequently in women with the most common site of occurrence being the uterus. Deep soft tissue leiomyomas are rare, and when they do occur are usually in adults and are usually in the extremities or pelvis. Leiomyomas are rare entities in the pediatric population, and deep soft tissue leiomyomas are even rarer lesions in children. Moreover, hernia sac neoplasms are in of themselves rare findings. We present to our knowledge the first case of a leiomyoma in the hernia sac of a child.
\end{abstract}

\section{Key words}

Leiomyoma, Hernia sac, Pediatric, Surgery

\section{Introduction}

Leiomyomas are smooth muscle neoplasms that can occur anywhere smooth muscle is found. Depending on the site of occurrence, leiomyomas are either relatively common or exceptionally rare. These neoplasms are common in the female genital tract, with an overall incidence of $4 \%$ to $11 \%$ and an incidence of nearly $40 \%$ in women greater than 50 years of age $^{[1]}$. They are also commonly found in the gastrointestinal tract and tracheobronchial tree. Despite their high incidence overall, leiomyomas are only rarely found in the deep soft tissue.

Leiomyomas are categorized by location into four general groups: cutaneous leiomyomas, which are found in the dermis and arise from the arrectores pilorum muscles; genital leiomyomas, which arise from smooth muscle bundles found in the genital areas; vascular leiomyomas, which arise from the smooth muscle of blood vessels; and deep-seated or retroperitoneal leiomyomas, which most commonly are located in the extremities, but can also be found in the pelvis ${ }^{[1]}$. Leiomyomas of the deep soft tissue are particularly rare given that most smooth muscle tumors found in the deep soft tissue are malignant. 
Leiomyomas of any type are rare in the pediatric population, and the anatomical distribution of leiomyomas in the pediatric population is very different from that in the adult population ${ }^{[2]}$. The rare cases of pediatric leiomyomas reported in the English literature occur predominately in the gastrointestinal and genitourinary tracts, with fewer reports in the extremities and deep soft tissue ${ }^{[3]}$. Although few reports have been published about leiomyomas in the hernia sacs of adults, there has been no such occurrence reported in the pediatric population. We report the first case of a leiomyoma in the hernia sac of a child.

\section{Case presentation}

A 2-year-old female with cerebral palsy, severe global developmental delay, seizure disorder, umbilical hernia, and dependence on tube feedings had recurrent aspiration pneumonias and severe gastroparesis. A Nissen fundoplication, pyloroplasty, and umbilical hernia repair were performed. At the time of umbilical exploration, the hernia sac was excised and sent for histopathologic examination.

On gross examination, the hernia sac consisted of two portions of irregular, pink-tan, translucent, vascularized tissue measuring $4.5 \mathrm{~cm} \times 2.0 \mathrm{~cm}$ in aggregate. Upon further examination, a $2.0 \mathrm{~cm} \times 0.3 \mathrm{~cm}$ well-circumscribed, firm mass was identified. The cut surface showed a solid, white, whorled appearance. There was no cystic change, hemorrhage, or necrosis.

Microscopic examination revealed a well-demarcated tumor composed of interlacing fascicles of smooth muscle cells in a whorling pattern, with intersecting bundles of collagen (see Figures 1A-1C). The lesion demonstrated long, monotonous spindle-shaped cells with blunted ends, nuclei with bland chromatin, and eosinophilic cytoplasm. There was no nuclear pleomorphism and mitoses were not identified. Necrosis was not evident. Immunohistochemical stains were performed, and tumor cells demonstrated positive staining for Caldesmon and Desmin (see Figures 2A-2B), and were negative for S-100 (see Figure 2C). Thus, the final pathologic diagnosis for the hernia sac specimen was leiomyoma.

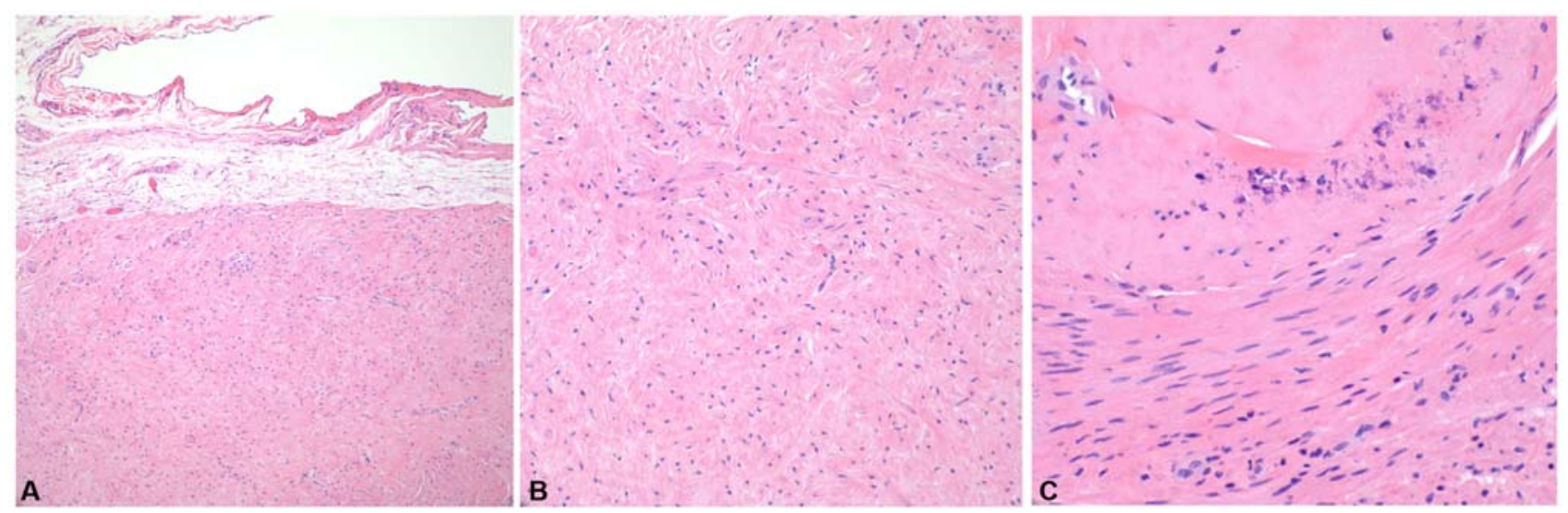

Figure 1. A. Hernia sac with leiomyoma, 10×. Histologic examination at low power demonstrates a well-demarcated tumor composed of smooth muscle cells underlying the mesothelial-lined hernia sac. The tumor is composed of whorled, anastomosing fascicles of uniform, fusiform smooth muscle cells. B. Leiomyoma, 20×. Higher magnification of the tumor shows spindle-shaped cells with indistinct borders and abundant fibrillar eosinophilic cytoplasm. C. Leiomyoma, 40×. Tumor cells demonstrate elongated nuclei with blunt ends with finely dispersed chromatin and scattered small nucleoli. Mitotic figures are not readily identified. Scattered areas of calcification are present.

The patient did well in the immediate post operative period. After the patient was stabilized, she was discharged and continued to do well in the subsequent weeks. 

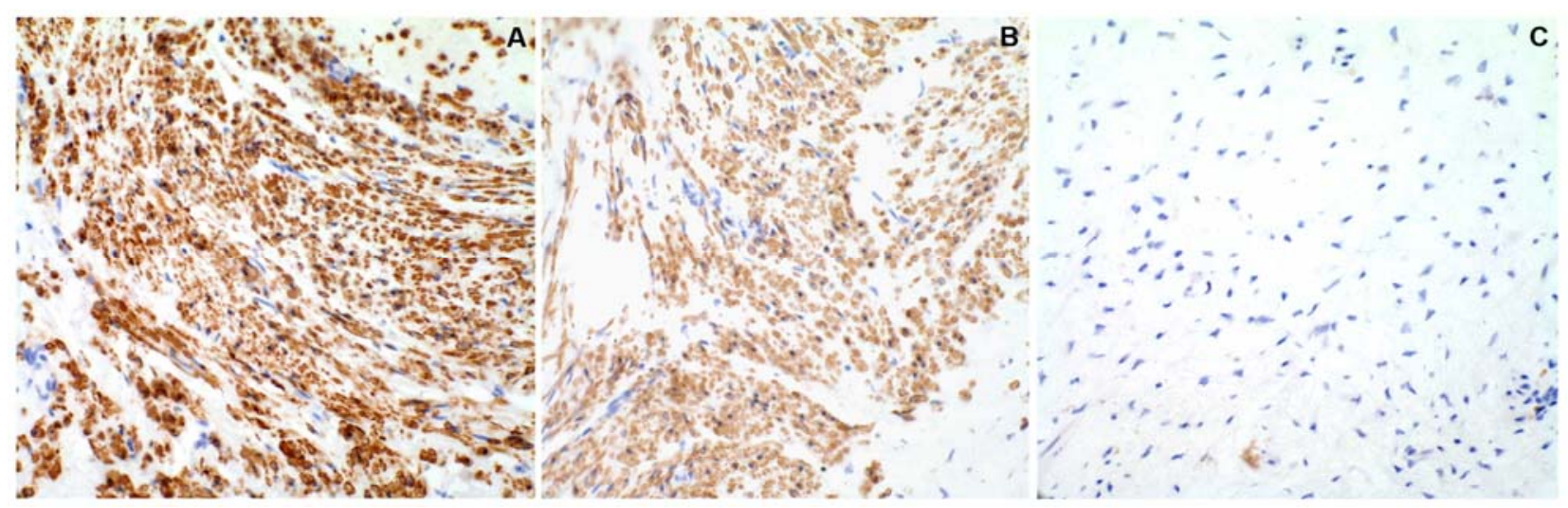

Figure 2. A. Tumor cells are strongly and diffusely immunoreactive for caldesmon. B. Tumor cells are strongly and diffusely immunoreactive for desmin. C. Tumor cells are negative for S100.

\section{Discussion}

Hernia sacs are one of the most common specimens in surgical pathology. Prior to the 1950's, the importance of histopathologic examination of hernia sacs after surgical repair was not clearly established. Examination was often limited to a superficial assessment of the gross specimen. However, publications began to arise that questioned this practice and that began to elucidate the importance of microscopic examination of hernia sacs. Notable was a 1959 case series by John Yoell of five cases of hernia sac removal with unexpected neoplastic findings ${ }^{[4]}$. Yoell emphasized that although not common occurrences, with only about $0.5 \%$ of surgically excised hernia sacs containing neoplasms, neoplastic processes in hernia sacs occurred with enough frequency that microscopic examination is necessary.

Rarely, mesothelioma or metastatic carcinoma will present in herniorrhaphy specimens. The most common primary sites are the gastrointestinal tract, ovary, prostate, and appendix ${ }^{[5,6]}$. There have also been case reports of metastatic carcinomas from the pericardium, tonsil, anorectum, and skin ${ }^{[4,7,8]}$. In addition, in very rare cases, viscid mucin deposits have been noted in inguinal hernias in patients with low-grade mucinous cystic tumors of the appendix ${ }^{[9]}$.

Leiomyomas are benign mesenchymal tumors that can occur anywhere smooth muscle is found. In the adult population, leiomyomas commonly affect the uterus but can also be found in the gastrointestinal tract, tracheobronchial tree, liver, adrenal glands, kidneys, and urinary bladder ${ }^{[10-13]}$. Leiomyomas are well-circumscribed and non-encapsulated tumors with a firm, gray-white, whorled surface on cut section. They are smooth muscle neoplasms characterized by intersecting fascicles of well-differentiated smooth muscle cells with spindled shape, blunt-ended, cigar-shaped nuclei, and brightly eosinophilic cytoplasm.

Leiomyomas and other smooth muscle tumors in children are rare ${ }^{[14]}$. Although histopathologically these tumors are identical to those found in adults, the anatomical distribution of leiomyomas in children is quite different than that of adults ${ }^{[3,15]}$. This is demonstrated by the finding that although uterine leiomyomas are the most common pelvic tumor in women ${ }^{[16-18]}$, leiomyomas of the uterus have been only occasionally described in adolescents and they have not been noted in prepubertal girls. A number of large case series have found the most common site of leiomyomas in the pediatric population to be the gastrointestinal tract (27\%), followed by the bladder (15\%), soft tissue (15\%), head and neck (11\%), and skin and subcutis $(9 \%)^{[3,14,19]}$.

Leiomyomas of the deep soft tissue are rare in any population, with a limited number of reported cases. The few reported cases in the literature most commonly arise in the deep subcutis or skeletal muscle ${ }^{[20]}$. The most common locations of occurrence were the extremities and the retroperitoneum, with fewer cases in the pelvis ${ }^{[20,21]}$. Deep soft tissue leiomyomas usually occur in adults in their fourth to sixth decades. 
Rare cases of leiomyomas in the hernia sacs of adults have been described in the literature. These cases vary from an incarcerated pedunculated fibroid in an umbilical hernia sac of a pregnant woman ${ }^{[22]}$ to an inguinal hernia of a uterine leiomyoma ${ }^{[23]}$. Thus, we report the present case due to its unusual presentation, the rare location of occurrence, and its rarity in the pediatric population. To our knowledge, this is the first reported case of a leiomyoma in the hernia sac of a child.

\section{References}

[1] Juan Rosai. Rosai and Ackerman's Surgical Pathology. 10th edition. 2011; Volume 2, 1508-1513; 2162-2163.

[2] Coffin CM, Dehner LP, O'Shea P. Pediatric soft tissue tumors: a clinical, pathological and therapeutic approach. Baltimore: Williams \& Wilkins. 1997; 238-50.

[3] Manojlovic S, et al. Calcified leiomyoma of the lateral pterygoid muscle in an 8-year-old boy. Oral and Maxillofacial Pathology. 2000; 89: 2.

[4] Yoell JH. Surprises in hernial sacs: diagnosis of tumors by microscopic examination. Calif Med. 1959; 91: 146-148. PMid: 13846556.

[5] Bostwick D, Eble J. Prostatic adenocarcinoma metastatic to inguinal hernia sac. J Urol Pathol. 1993; 1: $193-200$.

[6] Nicholson CP, Donohue JH, Thompson GB, et al. A study of metastatic cancer found during inguinal hernia repair. Cancer. 1992; 69: 3008-3011. http://dx.doi.org/10.1002/1097-0142(19920615)69:12<3008::AID-CNCR2820691224>3.0.CO;2-8

[7] Lowenfels AB, Rohman M, Ahmed N, et al. Hernia-sac cancer. Lancet. 1969; 1: 651. http://dx.doi.org/10.1016/S0140-6736(69)92013-3

[8] Goonewardena JN, Gallant V. Metastatic implants in hernial sacs. Ceylon Med J. 1977; 22: 96-98. PMid: 614099.

[9] Young RH, Rosenberg AE, Clement PB. Mucin deposits within inguinal hernia sacs: a presenting finding of low-grade mucinous cystic tumors of the appendix. A report of two cases and a review of the literature. Mod Pathol. 1997; 10: 1228-1232. PMid: 9436968.

[10] Jalgaonkar A, et al. Deep Soft Tissue Leiomyoma Mimicking Fibromatosis in a 5-year-old Male. J. of Foot \& Ankle Surgery. 2012; 51: 110-113. PMid: 22078158. http://dx.doi.org/10.1053/j.jfas.2011.10.013

[11] Hachisuga T, Hashimoto H, Enjoji M. Angioleiomyoma: a clinicopathologic reappraisal of 562 cases. Cancer. 1984; 54: 126-130. http://dx.doi.org/10.1002/1097-0142(19840701)54:1<126::AID-CNCR2820540125>3.0.CO;2-F

[12] Campanacci M. Bone and Soft Tissue Tumours. 2nd ed. New York: Piccin Nuova Libreria, Springer-Verlag; 1999.

[13] Turhan-Haktanir N, Haktanir A, Demir Y, et al. Toe leiomyoma: a case report with radiological correlation. Acta Chir Belg. 2006; 106: 92-95. PMid: 16612924.

[14] Yannapoulos K, Stout AP. Smooth muscle tumors in children. Cancer. 1962; 15: 958-71. http://dx.doi.org/10.1002/1097-0142(196209/10)15:5<958::AID-CNCR2820150511>3.0.CO;2-U

[15] López-Barea F, Rodríguez-Peralto JL, Burgos E, et al. Calcified leiomyoma of deep soft tissue: report of a case in childhood. Virchows Arch. 1994; 425: 217-20. PMid: 7952507. http://dx.doi.org/10.1007/BF00230360

[16] Baird DD, Dunson DB, Hill MC, et al. High cumulative incidence of uterine leiomyoma in black and white women: ultrasound evidence. Am J Obstet Gynecol. 2003; 188(1): 100. PMid: 12548202. http://dx.doi.org/10.1067/mob.2003.99

[17] Buttram VC Jr, Reiter RC. Uterine leiomyomata: etiology, symptomatology, and management. Fertil Steril. 1981 ; $36(4)$ : 433. PMid: 7026295.

[18] Serden SP, Brooks PG. Treatment of abnormal uterine bleeding with the gynecologic resectoscope. J Reprod Med. 1991; 36(10): 697. PMid: 1835500.

[19] Botting AJ, Soule EH, Brown AL. Smooth muscle tumors in children. Cancer. 1965; 18: 711-20. http://dx.doi.org/10.1002/1097-0142(196506)18:6<711::AID-CNCR2820180608>3.0.CO;2-4

[20] Kilpatrick SE, Mentzel T, Fletcher CD. Leiomyoma of deep soft tissue. Clinicopathologic analysis of a series. Am J Surg Pathol. 1994; 18: 576-582. PMid: 8179073. http://dx.doi.org/10.1097/00000478-199406000-00003

[21] Billings SD, Folpe AL, Weiss SW. Do leiomyomas of deep soft tissue exist? An analysis of highly differentiated smooth muscle tumors of deep soft tissue supporting two distinct subtypes. Am J Surg Pathol. 2001; 25: 1134-1142. PMid: 11688572. http://dx.doi.org/10.1097/00000478-200109000-00003

[22] Ehigiegba AE, Selo-Ojeme DO. Myomectomy in pregnancy: incarcerated pedunculated fibroid in an umbilical hernia sac. Int J Clin Pract. 1999; 53(1): 80. PMid:10344073.

[23] Kawakami S, et al. Uterine leiomyoma appearing as an inguinal mass. AJR Am J Roentgenol. 1997; 169(2): 547-8. PMid: 9242773. http://dx.doi.org/10.2214/ajr.169.2.9242773 